\title{
The Impact of Dizziness on Daily Activities in Patients with Temporomandibular Dysfunction
}

\author{
Bianca Simone Zeigelboim ${ }^{* 1}$, Larissa Vianna ${ }^{1}$, Adriana Lacerda ${ }^{1}$, Vinicius Ribas Fonseca ${ }^{1,2}$, José Stechman \\ Neto $^{1}$, Rubianne Ligório de Lima ${ }^{2}$, Jair Mendes Marques ${ }^{1}$ and Angela Ribas ${ }^{1}$ \\ ${ }^{1}$ Post Graduate Program in Communication Disorders, Universidade Tuiuti do Paraná, South America \\ ${ }^{2}$ ENT Service, Hospital da Cruz Vermelha Brasileira, South America
}

Submission: December 16, 2016; Published: January 06, 2017

*Corresponding author: Bianca Simone Zeigelboim, Universidade Tuiuti do Paraná (UTP) - Curitiba, Parana, Brazil, RuaGutemberg, 99, 9 ${ }^{\text {th }}$ floor, Postal Code: 80.420.030 - Curitiba, Parana, Brazil, Tel: (41) 3331-7807; Email: biancacwb@yahoo.com.br

\begin{abstract}
Objective: the objective of the study was to evaluate the impact of dizziness on the performance of daily practices in temporomandibular disorders (TMD) patients using the Activities-specific Balance Confidence Scale (ABC) and Dizziness Handicap Inventory (DHI) questionnaires.

Methods: we evaluated 20 women with a mean age of 52.3 years from February 2014 to July 2015. The following were carried out: anamnesis, ENT examination, vestibular examination, and application of DHI and ABC questionnaires.

Results: a) alterations were observed with a prevalence of peripheral vestibular deficit dysfunction independent of the affected side and dizziness for the emotional domain in the DHI;

b) The ABC confidence scale showed less confidence for questions 15 (Stepping onto or off an escalator while holding onto parcels so that you cannot hold the railing) and 16 (Walking outside on slippery sidewalks);

c) There was no significant correlation between the ABC confidence scale and the vestibular examination results or the symptom of dizziness.

Conclusion: based on the obtained results, it is noted that the applied DHI and ABC questionnaires showed sensitivity in quantifying the level of perception for balance disorders in patients and therefore the results may assist in choosing the most appropriate intervention.

Keywords: Temporomandibular joint; Dizziness; Quality of life; Labyrinth diseases

Abbreviations: TMD: Temporomandibular Disorders; ABC: Activities-specific Balance Confidence Scale; DHI: Dizziness Handicap Inventory; TMJ: Temporomandibular Joint Disorders; ENG: Electronystagmography; PL: Labyrinth Predominance; PDN: Directional Nystagmus Preponderance;
\end{abstract} PVDD: Peripheral Vestibular Deficit Dysfunction

\section{Introduction}

Temporomandibular disorders (TMD) are characterized by a series of clinical signs and symptoms such as: muscle aches, headache, joint cracking, difficulty and limitation in mandibular movements, tinnitus, earache, vertigo, dizziness, and hearing loss, among others [1,2]. The association of TMDs and the origin of otological symptoms is not yet fully understood, although there are some hypotheses about their relationship. Some authors [1,3-4] correlate these symptoms with temporomandibular joint disorders (TMJ) due to anatomical and structural proximity to the middle and inner ear. Other authors [5-7] have showed that otological symptoms, especially tinnitus, may derive from complex interactions and cross-modal mechanisms between somatosensory and auditory pathways. Dizziness may hinder a person's performance in daily activities such as those that require rapid movement of the head, and in tasks involving the trunk and head flexion [8].

Dizziness' interference in the daily activities can be assessed by validated questionnaires. Currently, there are questionnaires to evaluate the perception of dizziness and body imbalance, which allows one to quantify the impact of these symptoms on the daily life of patients. These questionnaires are considered important in the verification of the damage to daily life caused by symptoms. Among the existing instruments, we highlight the Dizziness Handicap Inventory (DHI) developed by Jacobson and Newman [9], which evaluates and quantifies the impact of dizziness on the individual's quality of life and the Activities-specific Balance Confidence Scale (ABC) developed by Powell and Myers [10], which uses a scale to measure an 


\section{Global Journal of Otolaryngology}

individual's self-confidence in performing daily activities. The aim of the study was to evaluate the impact of dizziness on the performance of daily tasks in TMD patients by using the ABC and DHI questionnaires.

\section{Methods}

20 female patients with temporomandibular disorders (TMD) and dizziness participated in the study, having been referred for evaluation to the Otoneurology Sector at Tuiuti University of Parana, located in Curitiba, Brazil, from February 2014 to July 2015. The study included patients with TMD and dizziness and excluded from the study TMD patients without complaints of dizziness and/ or those who had some type of alteration that prevented carrying out the proposed procedures. The subjects' ages ranged from 26 to 72 years (mean 52.3 years and standard deviation of 12.2 years). After completion of the vestibular examination, the $\mathrm{DHI}$ and $\mathrm{ABC}$ protocols were given. This is a descriptive cross-sectional study approved by the Ethics Committee in Opinion No. 0005769/12 and patients signed a consent form. Patients were subjected to a questionnaire with emphasis on otoneurological symptoms and ENT examination in order to rule out any alteration that could influence the adopted procedures. First, we checked for nystagmus and positional vertigo using the Brandt and Daroff exercise [11] and spontaneous and semi-spontaneous nystagmus.
Next, a electronystagmography (ENG) test was performed using a Berger VN316 model thermosensitive, São Paulo/SP/ Brazil device with three recording channels. After cleaning the skin in the periorbital region with alcohol, an active electrode was put on each patient, using conductive gel, on the lateral angle of each eye and the frontal midline, forming an isosceles triangle, which allowed for the identification of horizontal, vertical, and oblique eye movements. A Ferrante brand rotational chair was used along with a NeurograffEletromedicinaLtda, EV VEC visual stimulator, and a NeurograffEletromedicinaLtda, São Paulo/SP/ Brazil, NGR model 05 air calorimeter. The following ENG eye and labyrinthine tests were carried out according to the criteria proposed by several authors [12].

Calibration of ocular movements, test for spontaneous (open and closed eyes) and semi-spontaneous (open eyes) nystagmus, pendular tracking, optokinetic nystagmus, tests for pre- and post-rotatory and pre- and post-caloric nystagmus. The irrigation time of each ear with air at $42 \mathrm{oC}, 18 \mathrm{oC}$, and $10 \mathrm{oC}$ lasted 80 seconds at each temperature. Criteria used in the air caloric test: absolute value: between 2 and 24 degrees/ sec $(<2 \mathrm{deg} / \mathrm{sec}$ (hyporeflexia), > 24 degrees / sec (hyperreflexia); relative values: labyrinth predominance (PL) $<41 \%$ and directional nystagmus preponderance $(\mathrm{PDN})<36 \%$ [13].

\section{Application of the DHI questionnaire - Brazilian adaptation (Annex 1)}

Annex 1: Dizziness Handicap Inventory (DHI).

\begin{tabular}{|c|c|c|c|c|}
\hline \multicolumn{2}{|c|}{ Dizziness Handicap Inventory (DHI) } & \multicolumn{3}{|c|}{ Answers } \\
\hline \multirow[t]{3}{*}{ Sub-scale } & \multirow[t]{3}{*}{ Questions } & Yes & Sometimes & No \\
\hline & & \multicolumn{3}{|c|}{ Points } \\
\hline & & (4) & (2) & (0) \\
\hline Physical & $\begin{array}{l}\text { Does looking up or down worsens the } \\
\text { effects of dizziness? }\end{array}$ & & & \\
\hline Emotional & $\begin{array}{l}\text { Because of your disorder, do you feel } \\
\text { frustrated? }\end{array}$ & & & \\
\hline Functional & $\begin{array}{c}\text { Because of your disorder, do you restrict } \\
\text { your trips or work? }\end{array}$ & & & \\
\hline Physical & $\begin{array}{c}\text { Does walking in supermarket aisles worsen } \\
\text { your symptoms? }\end{array}$ & & & \\
\hline Functional & $\begin{array}{l}\text { Because of your problem, lying down or } \\
\text { getting out of bed? }\end{array}$ & & & \\
\hline Functional & $\begin{array}{l}\text { Does your disorder restrict your } \\
\text { participation in social activities? }\end{array}$ & & & \\
\hline Functional & $\begin{array}{l}\text { Because of your disorder, do you have } \\
\text { difficulty reading? }\end{array}$ & & & \\
\hline Physical & $\begin{array}{c}\text { Do sports activities or housework worsen } \\
\text { your symptoms? }\end{array}$ & & & \\
\hline Emotional & $\begin{array}{l}\text { Because of your disorder, are you afraid of } \\
\text { leaving the house alone? }\end{array}$ & & & \\
\hline Emotional & $\begin{array}{l}\text { Because of your disorder, do you feel } \\
\text { uncomfortable (ashamed) in front of others? }\end{array}$ & & & \\
\hline
\end{tabular}




\begin{tabular}{|c|c|c|}
\hline Physical & $\begin{array}{l}\text { Do rapid head movements worsen your } \\
\text { symptoms? }\end{array}$ & \\
\hline Functional & $\begin{array}{l}\text { Because of your disorder, do you avoid high } \\
\text { places? }\end{array}$ & \\
\hline Physical & $\begin{array}{l}\text { Does changing positions in bed, when lying } \\
\text { down, worsen your symptoms? }\end{array}$ & \\
\hline Functional & $\begin{array}{l}\text { Because of your disorder, has it become } \\
\text { more difficult to do heavy chores? }\end{array}$ & \\
\hline Emotional & $\begin{array}{l}\text { Because of your disorder, are you afraid } \\
\text { people will think you are drunk? }\end{array}$ & \\
\hline Functional & $\begin{array}{l}\text { Because of your disorder, is it difficult to } \\
\text { walk alone? }\end{array}$ & \\
\hline Physical & $\begin{array}{c}\text { Does walking on the sidewalk worsen your } \\
\text { symptoms? }\end{array}$ & \\
\hline Emotional & $\begin{array}{l}\text { Because of your disorder, is your } \\
\text { concentration affected? }\end{array}$ & \\
\hline Functional & $\begin{array}{l}\text { Because of your disorder, are you afraid to } \\
\text { walk in the dark? }\end{array}$ & \\
\hline Emotional & $\begin{array}{l}\text { Because of your disorder, are you afraid to } \\
\text { stay home alone? }\end{array}$ & \\
\hline Emotional & $\begin{array}{l}\text { Because of your disorder, do you feel } \\
\text { negatively affected? }\end{array}$ & \\
\hline Emotional & $\begin{array}{l}\text { Because of your disorder, have you had } \\
\text { relationship problems with friends or } \\
\text { family? }\end{array}$ & \\
\hline Emotional & $\begin{array}{l}\text { Because of your disorder, do you get } \\
\text { depressed? }\end{array}$ & \\
\hline Functional & $\begin{array}{c}\text { Does your disorder interfere with your } \\
\text { professional tasks? }\end{array}$ & \\
\hline Physical & Does lying down worsen your symptoms? & \\
\hline
\end{tabular}

This questionnaire was developed by Jacobson and Newman [9] and culturally adapted to the Brazilian population by Castro et al. [14] it aims to check the degree of disadvantage caused by dizziness in daily practice. The questionnaire consists of 25 questions, divided into questions about physical (seven questions), emotional (nine questions), and functional (nine questions) sub-scales. Patients can respond to questions using "yes" (worth four points), "sometimes" (worth two points), or "no" (worth zero points). The score ranges from 0 to 100 points and the closer to 100 , the greater the disadvantage caused by dizziness in the patient's life.

\section{Application of the $\mathrm{ABC}$ questionnaire - Brazilian adaptation (Annex 2)}

Annex 2: Activities-Specific Balance Confidence Scale (ABC).

\begin{tabular}{|c|c|}
\hline 1. Walking in house & 0 \\
\hline 2.Going up or down stairs & 0 \\
\hline 3.Bending to put object on floor & 100 \\
\hline 4.Reaching for a small can on a shelf at eye level & 0 \\
\hline 5.Standing on your toes to reach something above your head & 100 \\
\hline
\end{tabular}




\section{Global Journal of Otolaryngology}

\begin{tabular}{|c|c|c|}
\hline 6.Standing on a chair to reach for something & $\begin{array}{r}0 \\
---\end{array}$ & |--100 \\
\hline 7.Sweeping the floor & 0 & 100 \\
\hline 8.Walking outside the house to a car or bus parked in front & $\begin{array}{r}0 \\
-\cdots\end{array}$ & 100 \\
\hline 9.Getting into or out of a car & $\begin{array}{c}0 \\
-\cdots\end{array}$ & 100 \\
\hline 10.Walking across a parking lot to a supermarket or mall & $\begin{array}{c}0 \\
---.\end{array}$ & 100 \\
\hline 11.Walking up or down a ramp & $\begin{array}{c}0 \\
---.\end{array}$ & 100 \\
\hline 12.Walking in a crowded place & $\begin{array}{r}0 \\
---\end{array}$ & |--100 \\
\hline 13.Being bumped into as you walk through a crowded place & $\begin{array}{c}0 \\
-\cdots\end{array}$ & 100 \\
\hline 14.Stepping onto or off an escalator while holding onto the railing & $\begin{array}{r}0 \\
---\end{array}$ & | \\
\hline $\begin{array}{l}\text { 15.Stepping onto or off an escalator while holding onto parcels so that } \\
\text { you cannot hold the railing }\end{array}$ & 0 & 100 \\
\hline Walking outside on slippery sidewalks & 0 & 100 \\
\hline
\end{tabular}

Confidence Scale in Balance per Specific Activities

For each item below, score from 0 to 100 per line your confidence level in doing the activity without losing your balance or becoming unsteady.

This questionnaire was developed by Powell and Myers [10], and culturally adapted for Brazilians by Marques et al. [15] its objective is to evaluate an individual's level of confidence in his ability to maintain balance while performing specific daily activities. The questionnaire includes 16 questions about how confident the individual is in performing such tasks (no confidence $=0 \%$ and fully confident in carrying out the activity without losing balance $=100 \%$ ). Therefore, the higher the percentage, the greater the subject's confidence level.

\section{Statistical analysis}

A descriptive analysis was conducted for symptoms, the results of the vestibular examination, and the DHI. The Fisher test was used to verify the relationship between the results of the vestibular examination and dizziness symptoms. The Kruskal-Wallis test was used to compare the results of the DHI scores with the physical, functional and emotional domains. The Spearman correlation coefficient was applied to assess the relationship between the $\mathrm{ABC}$ questionnaire and dizziness (time of onset) and between the questionnaires $\mathrm{ABC}$ and DHI. The Fisher test verified the relationship between the DHI and ABC questionnaires with the results of vestibular examination and the DHI with dizziness symptoms. The rejection level of the null hypothesis was set at 0.05 or $5 \%$.

\section{Results}

Regarding complaints higher incidence of dizziness (100\%) was observed, followed by tinnitus, and headache with $80 \%$ each, as shown in (Table 1).

Table 1: Distribution of frequency of diverse otoneurological and clinical signs and symptoms in patients with TMD.

\begin{tabular}{|c|c|c|}
\hline $\begin{array}{c}\text { Signs and } \\
\text { Symptoms }\end{array}$ & $\begin{array}{c}\text { Absolute frequency } \\
\mathbf{N}\end{array}$ & $\begin{array}{c}\text { Relative Frequency } \\
\%\end{array}$ \\
\hline Dizziness & 20 & 100.0 \\
\hline Tinnitus & 16 & 80.0 \\
\hline Headache & 16 & 80.0 \\
\hline Anxiety & 15 & 75.0 \\
\hline Neck cracking & 8 & 40.0 \\
\hline $\begin{array}{c}\text { Tingling in } \\
\text { extremities }\end{array}$ & 8 & 40.0 \\
\hline
\end{tabular}




\begin{tabular}{|c|c|c|}
\hline Depression & 8 & 40.0 \\
\hline Insomnia & 7 & 35.0 \\
\hline Hearing loss & 6 & 30.0 \\
\hline Tingling & 3 & 15.0 \\
\hline Fatigue & 3 & 15.0 \\
\hline Facial paralysis & 1 & 5.0 \\
\hline
\end{tabular}

Source: Author Legend: TMD: Temporomandibular Dysfunction; N: Number of cases

The tests for positional nystagmus, eye movement calibration, spontaneous and semi-spontaneous nystagmus, pendular tracking, optokinetic and post-rotatory nystagmus, showed no alterations. The observed alterations occurred only in the caloric test. The caloric test showed a higher prevalence of normal reflexes in 11 cases (55\%), followed by unilateral hyporeflexia in seven cases (35\%), unilateral hyperreflexia and bilateral hyporeflexia both with one case (5\%) each. In nine subjects $(45 \%)$ there was peripheral vestibular dysfunction, eight cases of peripheral vestibular deficit dysfunction (40\%) and one case (5\%) of peripheral vestibular irritative dysfunction. The vestibular examination was normal in 11 cases (55\%).

The relationship between the results of the vestibular examination and dizziness found that there was no significant relationship using the Fisher test $(p=0.7105)$. Two categories of results from the vestibular examination, normal and altered, were used in applying the test. The descriptive statistics in the DHI with their respective domains were: 2.0 was the minimum and 24.0 was the maximum, with an average of 11.7 and a standard deviation of 6.7 for the physical domain; 0 minimum, 32.0 maximum, 14.3 average, 10.7 standard deviation for the emotional domain; 0 minimum, 28.0 maximum, 12.0 average, 9.0 standard deviation for the functional domain. In the application of the Kruskal-Wallis test, there was no statistically significant difference found $(\mathrm{p}=0.8055)$ between the results of the DHI scores and the evaluated domains.

The relationship of the DHI with the results of vestibular examination and dizziness can be seen in (Table 2).

Table 2: Relationship of DHI with vestibular exam results and symptom of dizziness.

\begin{tabular}{|c|c|c|c|c|}
\hline \multirow{2}{*}{$\begin{array}{c}\text { DHI Sub- } \\
\text { Scales }\end{array}$} & \multirow{2}{*}{ Scale } & \multicolumn{2}{|c|}{ ENG Result } & \multirow{2}{*}{ p } \\
\cline { 3 - 4 } & Altered & Normal & \\
\hline Physical & $\begin{array}{c}\text { Less than } \\
12\end{array}$ & 5 & 5 & 0.5000 \\
\hline & 12 or more & 4 & 6 & \\
\hline
\end{tabular}

\begin{tabular}{|c|c|c|c|c|}
\hline Emotional & $\begin{array}{l}\text { Less than } \\
\quad 12\end{array}$ & 5 & 4 & 0.3425 \\
\hline & 12 or more & 4 & 7 & \\
\hline \multirow[t]{2}{*}{ Functional } & $\begin{array}{l}\text { Less than } \\
12\end{array}$ & 3 & 5 & 0.4650 \\
\hline & 12 or more & 6 & 6 & \\
\hline \multirow[t]{2}{*}{$\begin{array}{l}\text { DHI Sub- } \\
\text { Scales }\end{array}$} & Scale & Dizziness & $\mathrm{p}$ & \\
\hline & & No & Yes & \\
\hline \multirow[t]{2}{*}{ Physical } & $\begin{array}{c}\text { Less than } \\
12\end{array}$ & 4 & 6 & 0.5000 \\
\hline & 12 or more & 5 & 5 & \\
\hline \multirow[t]{2}{*}{ Emotional } & $\begin{array}{l}\text { Less than } \\
12\end{array}$ & 2 & 7 & 0.0799 \\
\hline & 12 or more & 7 & 4 & \\
\hline \multirow[t]{2}{*}{ Functional } & $\begin{array}{l}\text { Less than } \\
12\end{array}$ & 3 & 5 & 0.4650 \\
\hline & 12 or more & 6 & 6 & \\
\hline
\end{tabular}

Legend: DHI: Dizziness Handicap Inventory; ENG: Electronystagmography

The Fisher test showed that there was no significant difference between the results of the vestibular examination, the DHI and dizziness, but there was a higher prevalence between the emotional domain and dizziness. In applying the test, two categories from the DHI (scale were used - less than 12 or 12 or higher) for each domain.

Table 3: $A B C$ scale results (mean, minimum, maximum and standard deviation).

\begin{tabular}{|c|c|c|c|c|c|}
\hline Questions & N & Mean & Minimum & Maximum & $\begin{array}{c}\text { Standard } \\
\text { Deviation }\end{array}$ \\
\hline 1 & 20 & $83.5 \%$ & $0.0 \%$ & $100.0 \%$ & $32.9 \%$ \\
\hline 2 & 19 & $72.6 \%$ & $0.0 \%$ & $100.0 \%$ & $31.4 \%$ \\
\hline 3 & 20 & $64.7 \%$ & $0.0 \%$ & $100.0 \%$ & $36.0 \%$ \\
\hline 4 & 19 & $77.9 \%$ & $0.0 \%$ & $100.0 \%$ & $35.4 \%$ \\
\hline 5 & 19 & $67.4 \%$ & $0.0 \%$ & $100.0 \%$ & $35.6 \%$ \\
\hline 7 & 19 & $62.7 \%$ & $0.0 \%$ & $100.0 \%$ & $41.4 \%$ \\
\hline 8 & 19 & $73.7 \%$ & $0.0 \%$ & $100.0 \%$ & $41.3 \%$ \\
\hline 9 & 18 & $71.7 \%$ & $0.0 \%$ & $100.0 \%$ & $40.0 \%$ \\
\hline
\end{tabular}


Global Journal of Otolaryngology

\begin{tabular}{|c|c|c|c|c|c|}
\hline 10 & 20 & $75.0 \%$ & $0.0 \%$ & $100.0 \%$ & $38.9 \%$ \\
\hline 11 & 20 & $73.0 \%$ & $0.0 \%$ & $100.0 \%$ & $38.0 \%$ \\
\hline 12 & 20 & $67.2 \%$ & $0.0 \%$ & $100.0 \%$ & $36.3 \%$ \\
\hline 13 & 18 & $67.8 \%$ & $0.0 \%$ & $100.0 \%$ & $37.3 \%$ \\
\hline 14 & 20 & $71.5 \%$ & $0.0 \%$ & $100.0 \%$ & $38.6 \%$ \\
\hline 15 & 20 & $36.0 \%$ & $0.0 \%$ & $100.0 \%$ & $37.9 \%$ \\
\hline 16 & 20 & $48.0 \%$ & $0.0 \%$ & $100.0 \%$ & $40.7 \%$ \\
\hline
\end{tabular}

Legend: ABC: Activities-Specific Balance Confidence Scale; N: Number of cases

The result of the $\mathrm{ABC}$ questionnaire can be seen in (Table 3). Note that questions 15 and 16 were the ones that had the lowest percentages of self-confidence in performance.

The relationship of the $\mathrm{ABC}$ questionnaire with dizziness (time of onset) and the results of vestibular examination, are listed in (Tables 4 \& 5).

Table 4: Relationship of $A B C$ scale with symptom of dizziness (start time).

\begin{tabular}{|c|c|c|c|}
\hline Questions & $\mathbf{N}$ & $\begin{array}{c}\text { Spearman } \\
\text { Correlation(R) }\end{array}$ & $\mathbf{P}$ \\
\hline Q1 & 20 & -0.0983 & 0.6801 \\
\hline Q2 & 19 & 0.3376 & 0.1575 \\
\hline Q3 & 20 & 0.2992 & 0.2000 \\
\hline Q4 & 19 & 0.2251 & 0.3541 \\
\hline Q5 & 19 & 0.1868 & 0.4438 \\
\hline Q6 & 19 & 0.4049 & 0.0855 \\
\hline Q7 & 19 & -0.0211 & 0.9317 \\
\hline Q8 & 19 & -0.0242 & 0.9216 \\
\hline Q9 & 18 & 0.0000 & 1.0000 \\
\hline Q10 & 20 & -0.2003 & 0.3973 \\
\hline Q11 & 20 & -0.0195 & 0.9351 \\
\hline Q12 & 20 & 0.2656 & 0.2578 \\
\hline Q13 & 18 & 0.2646 & 0.2886 \\
\hline Q14 & 20 & -0.0292 & 0.9027 \\
\hline Q15 & 20 & 0.2254 & 0.3392 \\
\hline Q16 & 20 & 0.0360 & 0.8803 \\
\hline
\end{tabular}

Legend: ABC: Activities-Specific Balance Confidence Scale

Table 5: Relationship of $A B C$ scale with the vestibular exam results (ENG).

\begin{tabular}{|c|c|c|c|c|}
\hline \multirow{2}{*}{ Questions } & \multirow{2}{*}{ Scale } & \multicolumn{2}{|c|}{ ENG } & \multirow{2}{*}{$\mathbf{P}$} \\
\hline & & Altered & Abnormal & \\
\hline \multirow[t]{2}{*}{ Q1 } & $\begin{array}{l}\text { Less than } \\
50\end{array}$ & 2 & - & 0.1895 \\
\hline & 50 or more & 7 & 11 & \\
\hline \multirow[t]{2}{*}{ Q2 } & $\begin{array}{l}\text { Less than } \\
50\end{array}$ & 2 & 3 & 0.5557 \\
\hline & 50 or more & 7 & 7 & \\
\hline \multirow[t]{2}{*}{ Q3 } & $\begin{array}{l}\text { Less than } \\
50\end{array}$ & 3 & 2 & 0.3955 \\
\hline & 50 or more & 6 & 9 & \\
\hline \multirow[t]{2}{*}{ Q4 } & $\begin{array}{l}\text { Less than } \\
50\end{array}$ & 2 & 1 & 0.3756 \\
\hline & 50 or more & 6 & 10 & \\
\hline \multirow[t]{2}{*}{ Q5 } & $\begin{array}{l}\text { Less than } \\
50\end{array}$ & 2 & 2 & 0.6672 \\
\hline & 50 or more & 7 & 8 & \\
\hline \multirow[t]{2}{*}{ Q6 } & $\begin{array}{l}\text { Less than } \\
50\end{array}$ & 4 & 3 & 0.4300 \\
\hline & 50 or more & 5 & 7 & \\
\hline \multirow[t]{2}{*}{ Q7 } & $\begin{array}{l}\text { Less than } \\
50\end{array}$ & 3 & 2 & 0.4443 \\
\hline & 50 or more & 6 & 8 & \\
\hline \multirow[t]{2}{*}{ Q8 } & $\begin{array}{l}\text { Less than } \\
50\end{array}$ & 3 & 2 & 0.4443 \\
\hline & 50 or more & 6 & 8 & \\
\hline \multirow[t]{2}{*}{ Q9 } & $\begin{array}{l}\text { Less than } \\
50\end{array}$ & 4 & 1 & 0.1471 \\
\hline & 50 or more & 5 & 8 & \\
\hline \multirow[t]{2}{*}{ Q10 } & $\begin{array}{l}\text { Less than } \\
50\end{array}$ & 3 & 1 & 0.2167 \\
\hline & 50 or more & 6 & 10 & \\
\hline \multirow[t]{2}{*}{ Q11 } & $\begin{array}{l}\text { Less than } \\
50\end{array}$ & 4 & 1 & 0.0975 \\
\hline & 50 or more & 5 & 10 & \\
\hline \multirow[t]{2}{*}{ Q12 } & $\begin{array}{l}\text { Less than } \\
50\end{array}$ & 4 & 1 & 0.0975 \\
\hline & 50 or more & 5 & 10 & \\
\hline \multirow[t]{2}{*}{ Q13 } & $\begin{array}{l}\text { Less than } \\
50\end{array}$ & 4 & 1 & 0.1471 \\
\hline & 50 or more & 5 & 8 & \\
\hline \multirow[t]{2}{*}{ Q14 } & $\begin{array}{l}\text { Less than } \\
50\end{array}$ & 3 & 2 & 0.3955 \\
\hline & 50 or more & 6 & 9 & \\
\hline \multirow[t]{2}{*}{ Q15 } & $\begin{array}{l}\text { Less than } \\
50\end{array}$ & 5 & 7 & 0.5350 \\
\hline & 50 or more & 4 & 4 & \\
\hline \multirow[t]{2}{*}{ Q16 } & $\begin{array}{l}\text { Less than } \\
50\end{array}$ & 5 & 5 & 0.5000 \\
\hline & 50 or more & 4 & 6 & \\
\hline
\end{tabular}




\section{Global Journal of Otolaryngology}

The Spearman correlation coefficient showed that there was no significant correlation between the $\mathrm{ABC}$ questionnaire and the time of onset of dizziness. The Fisher test showed that there was no significant relationship between the result of the
$\mathrm{ABC}$ questionnaire and that of the ENG. In applying the test there were two categories used - less than $50 \%$ and $50 \%$ or more. The unanswered questions were not taken into consideration.

Table 6: Spearman Correlation between $\mathrm{ABC}$ and $\mathrm{DH}$ questionnaires.

\begin{tabular}{|c|c|c|c|c|c|c|c|c|}
\hline \multirow{3}{*}{$\begin{array}{c}\mathrm{ABC} \\
\text { Questions }\end{array}$} & \multicolumn{8}{|c|}{ DHI } \\
\hline & \multicolumn{2}{|c|}{ Physical } & \multicolumn{2}{|c|}{ Emotional } & \multicolumn{2}{|c|}{ Functional } & \multicolumn{2}{|c|}{ Total } \\
\hline & $\mathbf{R}$ & $\mathbf{P}$ & $\mathbf{R}$ & $\mathbf{P}$ & $\mathbf{R}$ & $\mathbf{P}$ & $\mathbf{R}$ & $\mathbf{P}$ \\
\hline Q1 & 0.1745 & 0.4619 & 0.1833 & 0.4393 & 0.0330 & 0.8900 & 0.0651 & 0.7851 \\
\hline Q2 & 0.2615 & 0.2794 & 0.0491 & 0.8419 & 0.1407 & 0.5655 & 0.1550 & 0.5262 \\
\hline Q3 & 0.1805 & 0.4462 & 0.1231 & 0.6052 & 0.0753 & 0.7523 & 0.0888 & 0.7098 \\
\hline Q4 & 0.0153 & 0.9504 & 0.2674 & 0.2685 & 0.1430 & 0.5592 & 0.0275 & 0.9112 \\
\hline Q5 & 0.3343 & 0.1619 & 0.0354 & 0.8856 & 0.2306 & 0.3422 & 0.2281 & 0.3476 \\
\hline Q6 & 0.2020 & 0.4068 & 0.0345 & 0.8885 & 0.1523 & 0.5337 & 0.1141 & 0.6419 \\
\hline Q7 & 0.0259 & 0.9162 & 0.1688 & 0.4897 & 0.3024 & 0.2083 & 0.1342 & 0.5839 \\
\hline Q8 & 0.1399 & 0.5679 & 0.1950 & 0.4236 & 0.1252 & 0.6097 & 0.0363 & 0.8826 \\
\hline Q9 & 0.1585 & 0.5299 & 0.1028 & 0.6848 & 0.2964 & 0.2323 & 0.1948 & 0.4385 \\
\hline Q10 & 0.0424 & 0.8590 & 0.0351 & 0.8834 & 0.1984 & 0.4018 & 0.1466 & 0.5374 \\
\hline Q11 & 0.0820 & 0.7309 & 0.0619 & 0.7955 & 0.1977 & 0.4035 & 0.1225 & 0.6068 \\
\hline Q12 & 0.2506 & 0.2866 & 0.1403 & 0.5551 & 0.2486 & 0.2906 & 0.1271 & 0.5935 \\
\hline Q13 & 0.0775 & 0.7598 & 0.0234 & 0.9266 & 0.1210 & 0.6325 & 0.1046 & 0.6796 \\
\hline Q14 & 0.0225 & 0.9249 & 0.0973 & 0.6832 & 0.0386 & 0.8717 & 0.0261 & 0.9130 \\
\hline Q15 & 0.0046 & 0.9845 & 0.0835 & 0.7262 & 0.1133 & 0.6342 & 0.0142 & 0.9526 \\
\hline Q16 & 0.1375 & 0.5633 & 0.2353 & 0.3179 & 0.0977 & 0.6819 & 0.0624 & 0.7939 \\
\hline
\end{tabular}

Legend: ABC: Activities-Specific Balance Confidence Scale; DHI: Dizziness Handicap Inventory; R: Spearman Correlation

The relationship between the ABC and DHI questionnaires is shown in (Table 6). The Spearman correlation coefficient showed that there is no significant correlation between the ABC and DHI questionnaires.

\section{Discussion}

Symptoms of vertigo, tinnitus and headache observed in this study were also cited by authors [3,16-18]. Some authors [19] state that vertigo is responsible for approximately $54 \%$ of cases, being the most frequent otological symptom in patients with TMD. Some studies [20-24] correlated otoneurological signs and symptoms with TMD due to anatomical and structural proximity. Although Ramirez et al. [24] state that the abnormal activity of the tensor tympani muscle is associated with auditory and vestibular symptoms such as ear fullness, tinnitus, vertigo, hypo/ hyperacusis, and earache, for Mota et al. [25], the association of TMDs and the origin of otological symptoms are not very clear. There are several hypotheses about the relationship between otological symptoms and TMD. Studies [26] hypothesize this correlation based on three theories. The first one addresses the possibility of the mechanical transmission of force from the TMJ to the middle ear through the discomalleolar ligament.

The second refers to the possible direct irritation of the mandibular condyle of the auriculotemporal nerve. While the third, and most recent theory, focuses on the hypertonicity of the tensor muscles in the tympanum and the palatine veil, based on the common trigeminal innervation of these muscles and the masticatory muscles inserted in the mandible. For Watanabe et al. [27] this hypertonicity is related to tinnitus, due to spasms in the tensor muscle of the palatine veil which change the opening of the auditory tube, causing a tubal dysfunction that can lead to complaints of ear fullness, loss of hearing, tinnitus, otalgia and headaches. It can be verified that there is a correlation between the auditory and stomatognathic components. Such a connection may trigger auditory symptomatology in individuals with TMD. According to some authors [28], the mandible and ossicles of the middle ear have the same embryological origin, explaining why several malformations of the middle ear are associated with mandibular alterations. 


\section{Global Journal of Otolaryngology}

The anatomy and biomechanics of the TMJ are interrelated because they are closely related to aural structures and functions. Analyzing the results of the vestibular examination,it was observed that $45 \%$ of patients with TMD presented vestibular disorder with prevalence deficit. Zeigelboim et al. [18], in a study with TMD patients, observed labyrinthine alteration in $74 \%$ of cases with prevalence in labyrinthine deficit dysfunction. Hallan and Hinchcliffe [29] described that there is not always synchronicity between the malaise caused by vertigo and the results of otoneurological tests. The interference of dizziness in an individual's daily activities can be assessed by validated questionnaires to quantify its impact on patients' lives, and these questionnaires are considered important in the verification of the damage caused by this symptom. Among such questionnaires, the DHI used in this study showed that the emotional domain showed a higher average (14.3 points) followed by the functional and physical domains with 12.0 and 11.7 points, respectively.

The emotional domain indicates the involvement of the mental structure, that is, patients may present anxiety, panic, fear leaving the house unattended and/ or staying home alone, concern as to self-image, concentration disorders, feelings of inadequacy, and depression. These events were also observed by authors [30,31] who also observed a higher score in the emotional domain. In a study by Takano et al. [32] in an elderly population, it was possible to see greater difficulty in the functional domain, followed by emotional and physical. Kammerlind et al. [33] showed that individuals with symptoms had a lower quality of life and higher levels of anxiety and depression, which corroborated the present study in which the DHI emotional domain was the most affected, encompassing these symptoms.

The DHI scores were compared with the altered results from the vestibular examination and dizziness in order to verify the degree of harm to the subject's quality of life. Although there was no statistical significance, there was a prevalence of peripheral vestibular deficit dysfunction (PVDD) independent of the affected side and dizziness for the emotional domain on the DHI. Jacobson and Calder [34] also reported worse quality of life in patients with PVDD related to the total score of the domains evaluated in the DHI. PVDD clinically correlates with vestibular disorders in which there is partial or total reduction of vestibular function, with worse diagnosis regarding the peripheral vestibular irritative dysfunction. Usually, such cases can cause the destruction of the neurosensory epithelium of the membranous labyrinth and/ or fibers of the vestibular nerves, which in turn may cause intense and progressive dizziness [35].

Regarding the implementation of the $\mathrm{ABC}$ questionnaire, it was observed in the study that despite not having demonstrated statistical significance, the confidence level addressed in questions 15 (36\%) and 16 (48\%) were worse than those from other questions. The total score of this scale is the average of individual items, and, the lower the score, the less confident the individuals feel when performing such an activity. In the present study, less than $50 \%$ of subjects felt confident in the performance of these activities. For Lajoie and Gallagher [36] the $\mathrm{ABC}$ confidence scale had a sensitivity of $84.4 \%$ and specificity of $87.5 \%$ in a study of elderly. In another study in patients with hemiparesis, the authors, Braun et al. [37], also observed a confidence level of less than $50 \%$ in the $\mathrm{ABC}$ scale, but did not indicate in which of the 16 activities this percentage occurred.

The correlation between the $\mathrm{ABC}$ confidence scale, DHI domains, and the result of the vestibular examination, did not show a significant relationship. Dizziness may hinder the performance of an individual's daily activities, such as those that require rapid movement of the head and tasks involving trunk and head flexion [8]. Such movements may occur in the activities for questions 15 and 16, for which patients experienced greater difficulties. Also corroborating our findings were Munaro and Silveira [38] who reported that $40.8 \%$ of patients complained of dizziness related to change in head position. Koga et al. [39] also said that this finding may be related to the high incidence of dizziness due to certain positions of the head or changing head position. The authors Cole et al. [40] studied patients with Parkinson's disease and observed that the major changes in the $\mathrm{ABC}$ questionnaire occurred in questions 6 and 16 .

\section{Conclusion}

Based on the obtained results, it is noted that the applied $\mathrm{DHI}$ and $\mathrm{ABC}$ questionnaires showed sensitivity in quantifying the level of perception for balance disorders in patients and therefore the results may assist in choosing the most appropriate intervention.

\section{References}

1. Bell WE (1969) Clinical diagnosis of the pain dysfunction syndrome. J Am Dent Assoc 79(1): 154-160.

2. Siqueira JTT, Ching LH, Nasri C, Siqueira SRDT, Teixeira MJ, et al. (2004) Clinical study of patients with persistent orofacial pain. Arq Neuropsiquiatr 62(4): 988-996.

3. Morgan DH (1971) Dysfunction, pain, tinnitus, vertigo corrected by mandibular joint surgery. J South Calif Dent Assoc 39(7): 505-534.

4. Williamson EH (1990) The interrelationship of internal derangement of the temporomandibular joint, headache, vertigo and tinnitus: a survey of 25 patients. Cranio 8(4): 301-306.

5. Shore SE, Roberts LE, Langguth B (2016) Maladaptive plasticity in tinnitus: triggers, mechanisms and treatment. Nat Rev Neurol 12(3): 150-160.

6. Massimo Ralli, Giancarlo Altissimi, Rosaria Turchetta, Giancarlo Cianfrone, Filippo Mazzei, et al. (2017) Somatosensory tinnitus: correlation between history and somatic modulation-based screening to identify underlying cranio-cervico-mandibular disorders. Audiol Neurotol (in press).

7. Ralli M, Altissimi G, Turchetta R, Cianfrone G (2016) Somatic modulation of tinnitus: a review and some open questions. Otolaryngol Open J 2(4): 111-114.

8. Cohen H (1994) Vestibular rehabilitation improves daily life function. Am J Occup Therap 48(10): 919-925. 
9. Jacobson GP, Newman CW (1990) The development of the Dizziness Handicap Inventory. Arch Otolaryngol Head Neck Surg 152(6): 386391.

10. Powell LE, Myers AM (1995) The Activities-specific Balance Confidence (ABC) Scale. J Gerontol A BiolSci Med Sci 50(1): 28-34.

11. Brandt T, Daroff RB (1980) Physical therapy for benign paroxysmal positioning vertigo. Arch Otolaryngol 106(8): 484-485.

12. Mangabeira-Albernaz PL, Ganança MM, Pontes PAL (1976) Modelo operacional do aparelho vestibular. In: Mangabeira-Albernaz PL, Ganança MM. Vertigem. (2 ${ }^{\text {nd }}$ edn), Moderna, São Paulo, South America, p. 29-36.

13. Costa KCF, Silva SMR, Ganança CF (2005) Estudo das provas oculomotoras e vestibulares por meio da vectonistagmografia. Distúrbios Comum 17(3): 315-322.

14. Castro ASO, Gazzola JM, Natour J, Ganança FF (2007) Versão brasileira do Dizziness Handicap Inventory. CoDAS 19(1): 97-104.

15. Marques A, Mendes Y, Assumpção A, Pereira C, Taddei U (2013) Brazilian-Portuguese translation and cross cultural adaptation of the Activities-Specific Balance Confidence (ABC) Scale. Braz J Phys Ther 17(2): 170-178.

16. Chole RA, Parker WS (1992) Tinnitus and vertigo in patients with temporomandibular disorder. Arch Otolaryngol Head Neck Surg 118(8): 817-821.

17. Moraes AA, Gil D (2012) Tinnitus in individuals without hearing loss and its relationship with temporomandibular dysfunction. Braz J Otorhinolaryngol 78(2): 59-65.

18. Zeigelboim BS, Jurkiewicz AL, Martins-Bassetto J, Klagenberg KF (2007) Avaliação vestibular em mulheres com disfunção temporomandibular Rev CEFAC 9(2): 255-262.

19. Swartz R, Longwell P (2005) Treatment of vertigo. Am Fam Physician $7(6): 1115-1122$.

20. Koskinen J, Paavolainen M, Ravio M, Roschier J (1980) Otological manifestations in temporomandibular joint dysfunction. J Oral Rehabil $7(3): 249-254$.

21. Ash CM, Pinto OF (1991) The TMJ and the middle ear: structural and functional correlates for aural symptoms associated with temporomandibular joint dysfunction. Int J Prosthodont 4(1): 51-56.

22. Tuz HH, Onder EM, Kisnisci RS (2003) Prevalence of otologic complaints in patients with temporomandibular disorder. Am J Orthod Dentof Orthop 123(6): 620-623.

23. Machado IM, Pialarissi PR, Minici TD, Rotondi J, Ferreira LP (2010) Relation of the otological symptoms in the temporomandibular dysfunctions. Int Arch Otorhinolaryngol 14(3): 274-279.

24. Ramírez LM, Ballesteros LE, Sandoval GP (2007) Tensor tympani muscle: strange chewing muscle. Med Oral Patol Oral Cir Bucal 12(2): 96-100.

25. Mota LAA, Albuquerque KMG, Santos MHP, Travassos RO (2007) Signs and symptoms associated to otalgia in temporomandibular disorder. Int Arch Otorhinolaryngol 11(4): 411-415.

26. Manni UM, Brunori P, Giuliani M, Modoni M, Bizzi GI (1996) Sintomi otovestibolari nei pazienti com disfunzioni dell'articolazione temporomandibolare: studio elettromiografico. Minerva Stomatol 45(1-2): 1-7.

27. Watanabe I, Kumagami H, Tsuda Y (1974) Tinnitus due to abnormal contraction of stapedial muscle. An abnormal phenomenon in the course of facial nerve paralysis and its audiological significance. ORL J Otorhinolaryngol Relat Spec 36(4): 217-226.

28. D’Antonio W, Ikino CMY, Castro SM, Balbani APS, Jurado JRP, et al. (2000) Distúrbio temporomandibular como causa de otalgia: um estudo clínico. Rev Bras Otorrinolaringol 66(1): 46-50.

29. Hallan RS, Hinchcliffe R (1991) Emotional stability: Its relationship to confidence in maintaining balance. J Psychosom Res 35(4-5): 421-430.

30. Erlandsson SI, Rubinstein B, Axelsson UM, Carlsson SG (1991) Psychological dimensions in patients with disabling tinnitus anal craniomandibulares disorders. Br Audiol 25(1): 15-24.

31. Moreira DA, Bohlsen YA, Momensohn-Santos TM, Cherubini AA (2006) Study of the Handicap Caused by Dizziness in Patients Associated or Not with Tinnitus Complaint. Int Arch Otorhinolaryngol 10(4): 270277.

32. Takano NA, Cavalli SS, Ganaça MM, Caovilla HH, Santos MAO, et al. (2010) Quality of life in elderly with dizziness. Braz J Otorhinolaryngol 76(6): 769-775.

33. Kammerlind AS, Ledin TE, Skargren EI, Odkvist LM (2005) Longterm follow-up after acute unilateral vestibular loss and comparison between subjects with and without remaining symptoms. Acta Otolaryngol 125(9): 946-953.

34. Jacobson GP, Calder JH (2000) Self-perceived balance disability/ handicap in the presence of bilateral peripheral vestibular system impairment. J Am Acad Audiol 11(2): 76-83.

35. Ganança Fernando F, Castro Ana Silvia O, Branco Fatima C, Natour Jamil (2004) Impact of dizziness on the quality of life in patients with peripheral vestibular dysfunction. Braz J Otorhinolaryngol 70(1): 94101.

36. Lajoie Y, Gallagher SP (2004) Predicting falls within the elderly community: comparison of postural sway, reaction time, the Berg balance scale and Activities-specific balance confidence (ABC) scale for comparing fallers and non-fallers. Arch Gerontol Geriatric 38(1): 11-26.

37. Braun Aline, Herber Vanessa, Michaelsen Stella Maris (2012) Relação entre nível de atividade física, equilíbrio e qualidade de vida em indivíduos com hemiparesia. Rev Bras Med Esporte 18(1): 30-34.

38. Munaro Gisiane, Silveira AF (2009) Avaliação vestibular na vertigem posicional paroxística benigna típica e atípica. Rev CEFAC 11(1): 7684.

39. Koga KA, Resende BD, Mor R (2004) Estudo da prevalência de tontura/ vertigens e das alterações vestibulares relacionadas à mudança de posição de cabeça por meio da eletronistagmografia computadorizada. Rev CEFAC 6(2): 197-202.

40. Cole MH, Rippey J, Naughton GA, Silburn PA (2016) Use of a short-form balance confidence scale to predict future recurrent falls in people with parkinson disease. Arch Phys Med Rehabil 97(1): 152-156. 
Your next submission with JuniperPublishers will reach you the below assets

- Quality Editorial service

- Swift Peer Review

- Reprints availability

- E-prints Service

- Manuscript Podcast for convenient understanding

- Global attainment for your research

- Manuscript accessibility in different formats

( Pdf, E-pub, Full Text, Audio)

- Unceasing customer service

Track the below URL for one-step submission https://juniperpublishers.com/online-submission.php 